\title{
Analyzing of extracurricular program management technical in junior high school
}

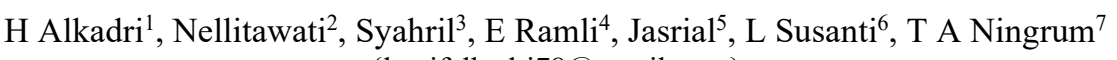 \\ \{hanifalkadri78@gmail.com\} \\ 1,2,3,4,5,6,7 Universitas Negeri Padang, J1. Prof Dr. Hamka Air Tawar, Padang, Indonesia
}

\begin{abstract}
The purpose of this article is to analyze of extracurricular program management technical in junior high school. Analyzing was done with mixed methods . They are qualitative and quantitative research. The results of the research are known that extracurricular program management technique can be managed by doing cooperation with the school, student and student guardian. According to the research, the students wants to do the extracurricular program because they agree about contribution of their technical or skill and character. Then student guardian and teacher is quite agreed if there is a contribution to make their student and children better.
\end{abstract}

\section{Introduction}

The character crisis is one of the problems that occur today [1]. The way to overcome it is by giving character education [2]. The form of character education management in schools is integrated into the intracurricular and extracurricular programs. Intracurricular activity is included in the teaching and learning process. While Extracurricular is educational activities outside the subjects to help develop students following their needs, potential, talents, and interests through activities specifically organized by capable educators and education personnel in school. Through sports activities, students are expected to be healthy, have deterrence, life force against drugs. Extracurricular program plays an important role in forming character and adding skills needed by students [3] [4] [5] [6] [7] [8] [9].

Then, extracurricular activities also influence the development of intelligence, personality, social attitudes and learning capacities. Students who take extracurricular activities since kindergarten will get benefit [10]. The participation of students in extracurricular activities can make students have high concern when they graduate [11]. Therefore, the management of the extracurricular program needs to be done. However, many extracurricular programs have not been effective because of financial problems. For this reason, it is necessary to analyze the management of extracurricular programs in schools.

\section{Method}

Research on the need for extracurricular programs in junior high schools in Pariaman city is a study with quantitative and qualitative methods. The method used is the sequential explanatory / mix method. The mix method is a combination research method of quantitative and qualitative methods sequentially [12]. In the first stage the research is carried out using a quantitative method and in the second stage is carried out by qualitative method. Quantitative 
method plays a role in obtaining descriptive quantitative data while qualitative method plays a role in proving, deepening, expanding, weakening quantitative data obtained in the initial stages. Population and sample used for quantitative research. The population in this study includes 9 schools consisting of 176 teachers, 2501 students, and 2501 parents. Sampling for this study uses the Krecji table. The number of samples for this study are 150 teachers and 350 students.

\section{Result and Discussion}

\subsection{Analysis of students contributions for extracurricular programs from the teacher perspective}

Based on the results of the study, an analysis of students contributions for extracurricular programs from the teacher's opinion can be seen in the graph below:

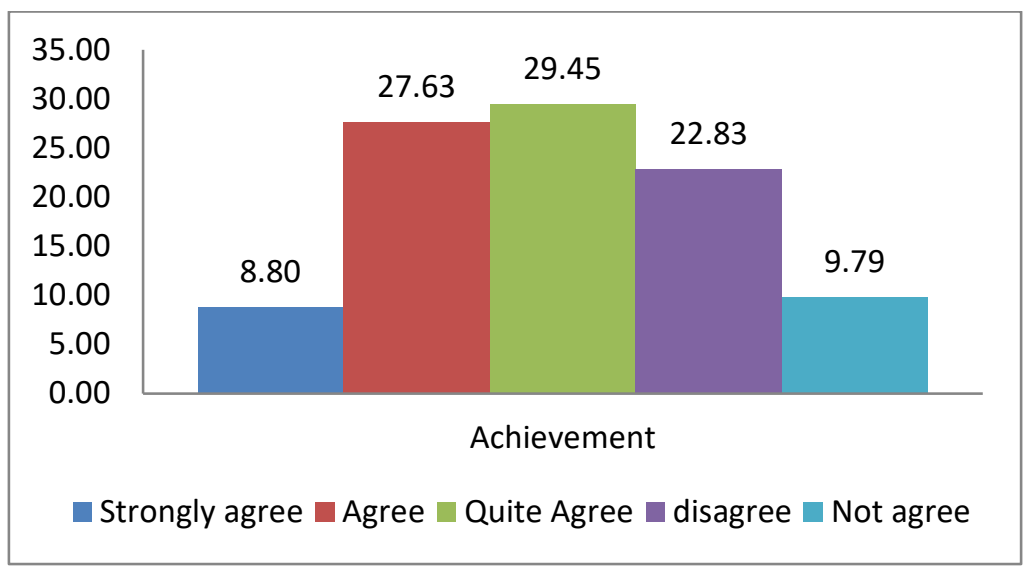

Figure 1. The table of student contributions frm the teacher's opinion

Based on the data above, $8.80 \%$ of teachers strongly agree on the existence of fund collection for extracurricular programs at school. As many as $27.63 \%$ of teachers stated that they agree with the fund collection for the Extracurricular Program at school. A total of $29.45 \%$ of teachers stated that they quite greed and $22.83 \%$ of teachers stated that they disagree with the existence of the fund collection. Meanwhile, a total of $9.79 \%$ of teachers stated that they did not agree to the fund collection for an extracurricular program at school. The data above illustrates that teachers in junior high schools in Pariaman City quite agree to collect the fund for extracurricular programs at school. This is indicated by number 29.45. Then based on the results of the questionnaire and interviews, it can be concluded that the teacher is quite agreeable to do the fund collection for extracurricular activities if the School Operational Assistance Fund (BOS) is insufficient for the implementation of extracurricular activities. Then, based on the results of interviews with several teachers and deputy principals, the teachers stated that fund collection is not necessary for students because it has been budgeted from the School Operational Assistance funds. Thus, the school does not want to collect fund from students. According to Kurniadi (2011), The school operational cost 
exemption policy for school programs needs to be studied more deeply because in the policy it is stated that schools are not permitted to collect fees from students [13].

\subsection{Analysis of students contributions for extracurricular programs from the students perspective}

Based on the results of the study, an analysis of students contributions for extracurricular programs from students opinion can be seen in the graph below.

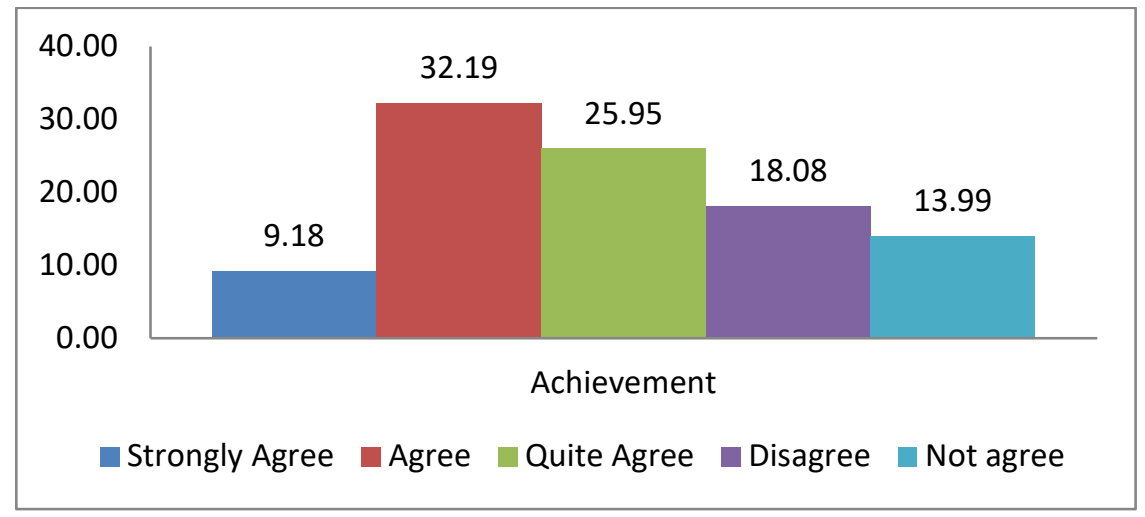

Fig.2. The table of student contributions frm the student's opinion

Based on the data above, 9,18\% of students strongly agree on the existence of fund collection for extracurricular programs at school. As many as 32,19\% of students stated that they agree with the fund collection for the Extracurricular Program at school. A total of 25,95 $\%$ of students stated that they quite greed and 18,08\% of students stated that they disagree with the existence of the fund collection. Meanwhile, a total of $13,99 \%$ of students stated that they do not agree to the fund collection for an extracurricular program at school. The data above illustrates that students in junior high schools in Pariaman City agree to collect the fund for extracurricular programs at school. This is indicated by number 32,19.

Based on interviews with students in junior high schools throughout Pariaman City, students agree to the funds collected for extracurricular activities. Based on interviews with informants, namely several students in junior high schools in Pariaman city, students agree and do not object to the collection of funds. Students argue the fund collection does not burden students and parents, moreover, it can be used to make extracurricular activities run smoothly. Students state that they do not mind if the fee is useful to implement and complete extracurricular program facilities.

Based on the results of the questionnaire and interview, it can be concluded that students agree if funds are collected for the implementation of extracurricular activities at school. Hopefully, the funds will be used as well as possible by the school to make the extracurricular activities run smoothly. Schools must be able to provide all the resources needed in extracurricular activities, including making funds collection if needed and students must invest in them [14] 


\subsection{Analysis of students contributions for extracurricular programs from the parents perspective}

Based on the results of the study, an analysis of students contributions for extracurricular programs from parents opinion can be seen in the graph below:

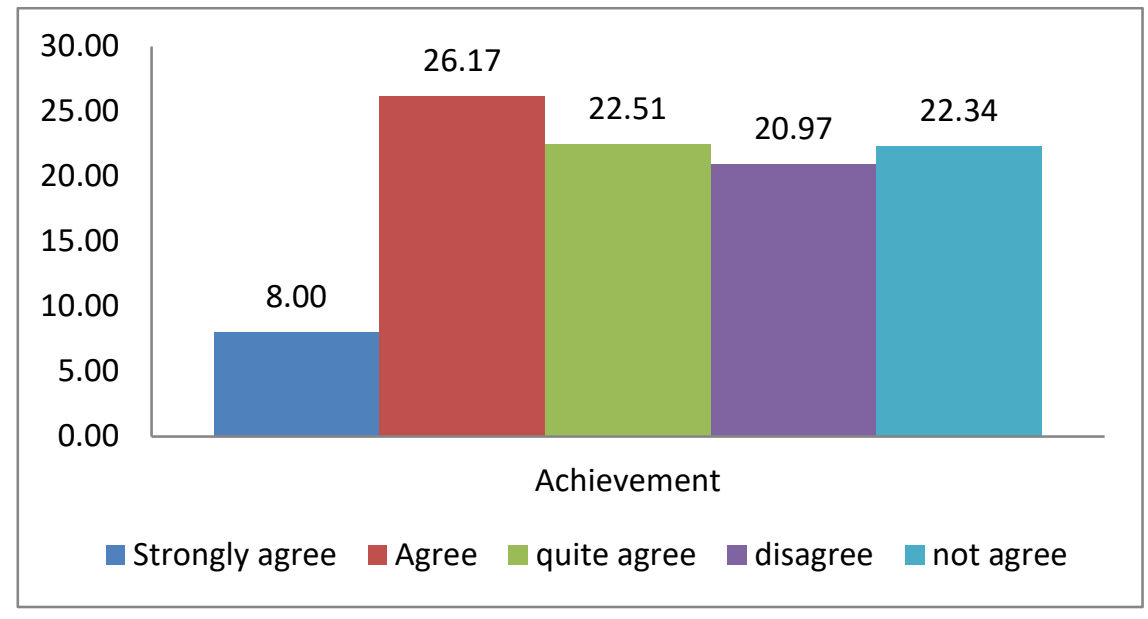

Fig.3. The table of student contributions frm the parent's opinion

Based on the data above, $8.00 \%$ of parents strongly agree on the existence of fund collection for extracurricular programs at school. As many as $26.17 \%$ of parents stated that they agree with the fund collection for the Extracurricular Program at school. A total of $22.51 \%$ of parents stated that they quite agree and $20.97 \%$ of parents stated that they disagree with the existence of the fund collection. Meanwhile, a total of $22.34 \%$ of parents stated that they do not agree to collect the fund for an extracurricular program at school. The data above illustrates that parents in junior high schools in Pariaman City agree to collect the fund for extracurricular programs at school. This is indicated by number 26.17 .

Based on interviews with parents, they agree to the funds collected for extracurricular activities. The parents agree and do not object to the collection of funds. They argue that the fund collection does not burden parents, moreover it can be used to make extracurricular activities run smoothly. Parents state that they do not mind collecting it if the fee is useful to implement and complete extracurricular program facilities.

Based on the results of the study, it is known that parents are welcome to give contributions to extracurricular programs if the funds used as well as possible. Schools are not permitted to collect fees from students if it causes students and parents to feel a burden. While the results of the study reveal that parents agree with the fund collection for the extracurricular program if it can be used properly, clearly and transparently [15].

\subsection{Fund management for extracurricular programs}

Management is an activity starting from planning, implementation, and evaluation[16] . Funds are one of the important components in management [17]. In the early stages of management, a planning process is carried out with a need for analysis. 
Based on the results of the study, it is known that the school namely teachers, students, and parents agree to apply the school contribution policy. The data above illustrates that in junior high schools in Pariaman city teachers are quite agreeable to collect the fund for extracurricular programs at school. This is indicated by the number 29.45 from the teacher.

\section{Conclusion}

Fund management for extracurricular programs can be done in collaboration between the school, students, and parents. Based on the results of the study, it is known that the contribution policy for students is well applied in schools. This is because teachers, students, and parents agree to apply the school contribution policy.

\section{Acknowledgment}

Thank you to Universitas Negeri Padang for permitting this research.

\section{References}

[1] Sumarni S, Dardiri A and Zuchdi D 2015 Jurnal Pembangunan Pendidikan: Fondasi Dan Aplikasi 350

[2] Ramdhani M T, Supriadi S dan Hunainah H 2017 PengabdianMu: Jurnal Ilmiah Pengabdian Kepada Masyarakat 2120

[3] Dewi N K and Saragih S 2015 Persona: Jurnal Psikologi Indonesia 3255

[4] Lismadiana 2006 Jurnal Olahraga Prestasi 26

[5] Prasetyo Y 2010 Jurnal Pendidikan Jasmani Indonesia 78

[6] Rachmawati S N I 2016 Upaya Pembentukan karakater siswa melalui kegiatan Ekstrkurikuler Pencak Silat di MI Sulta Agung Babadan Baru Sleman (Yogyakarta:Universitas Islam Negeri Sunan Kalijaga)

[7] Effendi M S 2015 Pendidikan karakter siswa melalui kegiatan ekstrakurikuler keagamaan kerohanian Islam di SMPN 1 Probolinggo (Bandung: Universitas Islam Negeri Maulana Malik Ibrahim)

[8] Yanti N, Adawiah R and Matnuh H 2016 Jurnal Pendidikan Kewarganegaraan 69

[9] Kurniawan F and Karyono T 2010 Jurnal Bebas 116

[10] Chiu C Y and Lau E Y H 2018 Children and Youth Services Review 88476

[11] White T and Michelle R M 2018 Children and Youth Services Journal 85593

[12] Sugiyono 2013 Metode Penelitian Manajemen. Pendekatan: Kuantitatif, Kualitatif, Kombinasi (Mixed Methods), Penelitian Tindakan (Action Research), Penelitian Evaluasi (Bandung: Alfabeta)

[13] D A Kurniady 2011 Jurnal Penelitian Pendidikan 1234

[14] Stearns E, Potochnick S, Moller S and Southworth S 2010 Research in Higher Education 51366

[15] Nurcahyo F 2013 Jurnal Pendidikan Jasmani Indonesia 98

[16] Stoner J A.F 1996 Management (Jakarta: Erlangga)

[17] Usman H 2012 Manajemen: Teori, praktik dan Riset Pendidikan (Jakarta: Bumi Aksara) 